\title{
PEMBIASAAN TRADISI ASWAJA SEBAGAI UPAYA PENCEGAHAN RADIKALISME DI MADRASAH ALIYAH MATHOLI'UL HUDA KEDUNG JEPARA
}

\author{
Fathur Rohman'; Hanifa A'la ${ }^{2}$ \\ 1,2 Universitas Islam Nahdlatul Ulama Jepara
}

\begin{abstract}
ABSTRAK
Artikel ini membahas tentang praktik-praktik tradisi Aswaja yang dilaksanakan di Madrasah Aliyah (MA) Matholi'ul Huda Kedung Jepara sebagai salah satu sarana untuk mencegah radikalisme. Ada dua masalah yang akan dibahas dalam artikel ini, yaitu bentuk-bentuk tradisi Aswaja yang berjalan di MA Matholi'ul Huda Kedung Jepara dan pembiasaan tradisi Aswaja di lingkungan MA Matholi'ul Huda Jepara. Kajian ini dilakukan dengan menggunakan pendekatan kualitatif dengan metode studi kasus. Data dalam penelitian ini dikumpulkan dengan teknik observasi peran serta, wawancara, dan dokumentasi. Data kemudian dianalisis secara deskriptif kualitatif melalui tiga tahapan, yaitu penyajian, reduksi, dan verifikasi. Dari hasil analisis tersebut, diketahui bahwa tradisi yang dibiasakan di MA Matholi'ul Huda Kedung Jepara adalah khatmil qur'an, tahlilan, istigtsah, ziarah kubur, dan tawassul. Khatmil Qur'an dan Tahlilan dibiasakan setiap seminggu sekali. Sementara Istighatsah, ziarah kubur, dan tawassul dilakukan di awal tahun pelajaran, menjelang ujian semester, dan Ujian Nasional. Pembiasaan tradisi tersebut merupakan bentuk pembelajaran agar siswa memiliki sikap kepedulian terhadap tradisi dan penghargaan terhadap para ulama yang telah memulai tradisi tersebut. Sikap peduli dan menghargai inilah yang pada gilirannya akan menjadi penangkal sekaligus penawar bagi "racun" radikalisme.
\end{abstract}

Kata Kunci: Tradisi, Spiritualitas, Ahlus Sunnah wal Jama’ah, Radikalisme.

\section{ABSTRACT}

This article discusses the traditional Aswaja practices that implemented in Madrasah Aliyah (MA) Matholi'ul Huda Kedung Jepara as a means of preventing radicalism. There are two issues that will be discussed in this article, namely the forms of the Aswaja tradition that took place in MA Matholi'ul Huda Kedung Jepara and the habituation of the Aswaja tradition within the MA Matholi'ul Huda Jepara. This study was conducted using a qualitative approach with a case study method. The data in this study were collected using participatory observation techniques, interviews, and documentation. The data were then analyzed descriptively qualitatively through three stages, namely presentation, reduction and verification. From the results of this analysis, it is known that the traditions that are accustomed to in MA Matholi'ul Huda Kedung Jepara are khatmil quran, tahlilan, istigtsah, pilgrimage to the grave, and tawassul. Khatmil Qur'an and Tahlilan habituated once a week. While Istighatsah, grave pilgrimage, and tawassul are carried out at the beginning of the school year, before the semester exams, and the National Examination. This traditional habituation is a form of learning so that students have a caring attitude towards tradition and respect for the scholars who have started the tradition. This attitude of caring and respect will in turn be both an antidote and an antidote to the "poison" of radicalism.

Keywords: Tradition, Spirituality, Ahlus Sunnah wal Jama'ah, Radicalism. 


\section{A. Pendahuluan}

Radikalisme atas nama agama saat ini telah menjadi musuh bersama bagi hampir semua bangsa di dunia. Berawal dari tragedi 11/9, radikalisme agama saat ini telah menjadi isu global. Meskipun telah berlalu lebih dari satu dekade, tidak ada tanda-tanda radikalisme akan surut. Sebaliknya, perkembangan terbaru tidak hanya menunjukkan bahwa radikalisme tetap menjadi masalah besar bagi dunia, tetapi masih akan terjadi dalam beberapa waktu ke depan. ${ }^{1}$

Tak terkecuali di Indonesia, Radikalisme agama menjadi sebuah fenomena yang semakin marak dalam beberapa tahun akhir, bahkan berujung pada terorisme. Salah satu indikasinya adalah kemunculan kelompok atau organisasi-organisasi keagamaan yang hobi menggunakan cara-cara kekerasan dalam menjalankan misinya. Lebih dari itu, buah nyata dari penyebaran radikalisme bisa dilihat dari aksi-aksi terorisme yang dilancarkan oleh para simpatisan ISIS, misalnya bom Thamrin pada 2016, bom Kampung Melayu pada 2017, dan serangkaian teror beruntun pada Mei 2018 di Gereja dan Polretabes Surabaya yang melibatkan satu keluarga, serta penyerangan terhadap kantor polisi Pekanbaru. ${ }^{2}$

Meskipun kelompok Islam radikal di berbagai negara muslim tersebut, notabene adalah kelompok minoritas, namun tindakan dan perjuangan mereka cukup mewarnai dinamika kehidupan sosial-keagamaan. Beberapa studi tentang gerakan radikal menyimpulkan bahwa kelompok radikal tidaklah tunggal. Ada banyak gerakan dalam komunitas Islam radikal yang masing-masing memiliki visi, orientasi, dan arah gerakan yang unik, bahkan tidak jarang terlibat konflik satu sama lain. Namun satu hal yang hampir bisa dipastikan adalah semua gerakan tersebut memiliki kesamaan karakter, yaitu menyetujui cara-cara ekstrem yang pada tahap tertentu sampai pada kekerasan untuk mencapai tujuan. ${ }^{3}$

Kelompok-kelompok tersebut, u mumnya membawa slogan kembali kepada Al-Qur'an dan Hadits nabi, sehingga apapun yang tidak sesuai dengan Al-qur'an dan Hadits dianggap bid'ah dan sesat. Pun demikian, pemahaman mereka terhadap kedua sumber ajaran Islam tersebut cenderung tekstualis. Teks al-Qur'an dan hadits dalam

1 Hamed El-Said, New Approaches to Countering Terrorism Designing and Evaluating Counter Radicalization and De-Radicalization Programs (London: Palgrave Macmillan, 2015).

2 Bilveer Singh, "Terrorist Attacks in Indonesia: Insights for Practicioners and Policymakers," in Learning From Violent Extremist Attacks: Behavioural Sciences Insights For Practitioners And Policymakers (Toh Tuck Link, Singapore: World Scientific, 2019), 8.

${ }^{3}$ Ngainun Naim, "Deradicalization Through Islamic Education at State Institute for Islamic Studies (IAIN) Tulungagung,” Madania 22, no. 2 (2018): 211-224. 
pandangan kelompok ini harus dimaknai secara harfiah sebagaimana bunyinya karena akal dianggap tidak cukup mampu memberikan penafsiran yang tepat terhadap teks. ${ }^{4}$

Eksistensi kelompok-kelompok radikal tersebut tentu saja akan menjadi ancaman bagi masa depan Islam Indonesia. Sejauh ini, Islam Indonesia dikenal dengan karakter damai, ramah, dan toleran. Dinamika dan perkembangan Islam di Indonesia selama ratusan tahun lamanya telah menunjukkan bahwa Islam yang damai dapat menyatu dengan masyarakat Indonesia. Islam radikal sampai kapanpun tidak memilki harapan hidup di masa depan. Hal ini disebabkan oleh salah satunya penolakan yang dilakukan oleh kelompok Islam radikal terhadap kearifan nilai-nilai tradisi dan budaya lokal Indonesia. ${ }^{5}$

Pendidikan menjadi salah satu pintu paling efektif bagi penyebaran ideologi radikal. Bisa dicermati, dewasa ini telah lahir banyak lembaga pendidikan Islam di semua jenjang, mulai dari pendidikan usia dini hingga pendidikan menengah yang beafiliasi kepada ormas-ormas radikal. Berbagai kajian tentang radikalisme dan terorisme mensinyalir adanya lembaga pendidikan, terutama lembaga pendidikan Islam baik formal atau non formal, yang menyusupkan radikalisme kepada para peserta didik. Setara Institute misalnya, dalam penelitiannya pernah merilis daftar pesantren yang berkongsi dengan gerakan radikal transnasional di Jawa Tengah dan Yogyakarta. Beberapa dari pesantren tersebut merupakan pusat utama penyebaran ideologi radikal di Indonesia. ${ }^{6}$

Ciri-ciri umum lembaga pendidikan semacam ini biasanya sangat lekat dengan budaya Timur Tengah, tekstualis dalam memahami ajaran agama, dan menggunakan istilah-istilah berbau Arab seperti Daurah, Halaqah, Mabit, dan sebagainya. Meskipun tampil dengan sistem pendidikan dan tingkat radikalisme yang berbeda-beda, tetapi mereka memiliki cita-cita yang sama, yaitu menegakkan syari’at Islam di Indonesia. Karenanya, Tradisi dan budaya Islam indonesia yang telah terbangun berabad-abad dianggap bid'ah, syirik, dan kufur karena bertentangan dengan syari'at versi mereka, tak terkecuali konsep NKRI dan dasar negara Pancasila. Ajaran semacam inilah yang

4 Junaidi Abdillah, “Radikalisme Agama: Dekonstruksi Tafsir Ayat-Ayat 'Kekerasan' Dalam Al-Qur'an,” KALAM 8, no. 2 (February 22, 2017): 281-300.

${ }^{5}$ Wasid Mansyur, Menegaskan Islam Indonesia, Belajar Dari Tradisi Pesantren Dan NU (Surabaya: Pustaka Idea, 2014).

6 Ismail Hasani and Bonar Tigor Naipospos, Dari Radikalisme Menuju Terorisme (Jakarta: Pustaka Masyarakat Setara, 2012). 39 
disinyalir oleh berbagai pihak menjadi landasan dan akar berbagai tindakan teror di Indonesia. ${ }^{7}$

Baru-baru ini diberitakan beberapa lembaga pendidikan formal diberitakan melarang peserta didiknya melakukan penghormatan bendera merah putih dan menyanyikan lagu kebangsaan karena dianggap dapat menimbulkan syirik. ${ }^{8}$ Ada pula oknum guru di sebuah lembaga pendidikan yang melarang peserta didiknya sungkeman kepada orang tua dengan alasan yang sama. ${ }^{9}$ Pusat Pengkajian Islam dan Masyarakat (PPIM) UIN Syarif Hidayatullah Jakarta dalam surveynya tahun 2017, juga mengungkapkan bahwa dari 1522 peserta didik dan 337 mahapeserta didik di 34 provinsi dan $68 \mathrm{kab} / \mathrm{kota}$, 58.5\% di antaranya memiliki pandangan keagamaan radikal, sementara $7.0 \%$ dari itu bersedia melakukan tindakan radikal. ${ }^{10}$ Fakta dan data tersebut, kiranya cukup sebagai bukti bahwa lembaga pendidikan menjadi lahan subur penyebaran radikalisme. Jika tidak segera diantisipasi, bukan tidak mungkin benihbenih radikalisme tersebut akan menyebar luas. Meluasnya radikalisme akan memperkecil peluang membangun harmoni sosial dalam masyarakat Indonesia yang multikultural. Sementara peluang kekerasan dan intoleransi akan semakin meluas. Karena itulah, dibutuhkan upaya sistematis untuk mencegah tumbuh dan berkembangnya radikalisme. ${ }^{11}$

Salah satu upaya yang sudah dilakukan adalah dengan menanamkan nilai-nilai paham ahl al-sunnah wa al-jama'ah. Ajaran aswaja memiliki potensi untuk menjadi sarana membangun pemahaman Islam yang inklusif, dan moderat. Selain itu, Aswaja yang tertanam sebagai pengetahuan, pemahaman dan sikap merupakan modal penting untuk bersikap kritis dalam mengahdapi dinamika sosial keagamaan yang semakin kompleks. ${ }^{12}$ Hal ini karena Aswaja memiliki watak dasar moderat (tawassuth), di samping juga adil (i’tidal), seimbang (tawazun), dan toleran (tasamuh). Adanya

7 Abu Rokhmad, “Radikalisme Islam dan Upaya Deradikalisasi Paham Radikal," Walisongo: Jurnal Penelitian Sosial Keagamaan 20, no. 1 (May 30, 2012): 81.

8 Media Indonesia, "Sekolah Larang Hormat Bendera," Mediaindonesia.Com, September 1, 2016, http://mediaindonesia.com/news/read/64540/sekolah-larang-hormat-bendera/2016-09-01.

${ }^{9}$ Kompas, "Larang Murid Hormat Bendera Dan Sungkem Orangtua, Guru SD Diberhentikan," Kompas. Com, January 26, 2016, http://regional.kompas.com/read/2016/01/26/11533721/Larang.Murid.Hormat. Bendera.dan.Sungkem. Orangtua.Guru.SD.Diberhentikan.

10 Tim PPIM UIN Syarif Hidayatullah Jakarta, “Api Dalam Sekam” Keberagamaan Muslim Gen-Z, Survei Nasional Tentang Keberagamaan Di Sekolah Dan Universitas Di Indonesia (Jakarta: PPIM UIN Syarif Hidayatullah Jakarta, 2017).

${ }^{11}$ Ngainun Naim, "Pengembangan Pendidikan Aswaja sebagai Strategi Deradikalisasi," Walisongo: Jurnal Penelitian Sosial Keagamaan 23, no. 1 (June 15, 2015): 69-88.

12 Didin Wahyudin, "Pendidikan Aswaja sebagai upaya menangkal radikalisme," Dinamika Penelitian: Media Komunikasi Penelitian Sosial Keagamaan 17, no. 2 (2017): 291-314. 
prinsip-prinsip tersebut dalam tubuh Aswaja, menjadikan Aswaja secara otomatis kebal dan menolak terhadap segala bentuk tindakan dan pemikiran ekstrem (tatharruf). ${ }^{13}$

Salah satu cara menanamkan nilai-nilai Aswaja, terutama bagi pelajar, adalah melalui pendidikan Aswaja. Di lembaga-lembaga pendidikan milik NU, materi Aswaja menjadi salah satu muatan wajib dari tingkat dasar hingga perguruan tinggi. Pembelajaran Aswaja bertujuan untuk memperkenalkan dan menanamkan nila-nilai aswaja secara keseluruhan kepada peserta didik, sehingga menjadi muslim yang terus berkembang dalam hal keyakinan, ketakwaan kepada Allah, serta berakhlak mulia sebagi individu maupun anggota masyarakat, sesuai ajaran Islam berhaluan Ahl alsunnah wa al-jama'ah yang dicontohkan oleh jama'ah, mulai dari sahabat, tabi'it tabi'in, dan para ulama generasi dari generasi ke generasi. ${ }^{14}$

Selain dalam bentuk pembelajaran di kelas, penanaman nilai-nilai aswaja juga banyak dilakukan dengan metode pembiasaan terhadap amaliah Aswaja. Amaliah bisa dikatakan sebagai perbuatan atau perilaku keseharian yang berhubungan dengan agama. Bahasa sederhananya, amaliah juga bisa disebut dengan tradisi yang berkaitan dengan agama. Melalui pembiasaan tradisi Aswaja tersebut diharapkan akan tertanam nilai-nilai Aswaja dalam diri seseorang yang pada gilirannya akan menjadi penangkal ideologi radikal. Hal ini sebagaimana dilakukan oleh Madrasah Aliyah Matholi'ul Huda Jepara. Sebagai madrasah yang berlatar belakang Sunni, pendidikan Aswaja tidak hanya dilakukan melalui pembelajaran di dalam kelas, tetapi juga dengan pembiasaan praktik tradisi Aswaja dalam keseharian guru dan peserta didik. Pembiasaan tradisi ini dimaksudkan untuk memelihara tradisi keagamaan ala Aswaja yang telah diajarkan secara turun-temurun oleh para ulama terdahulu, tetapi juga untuk membentengi peserta didik dari radikalisme yang menyerang melalui berbagai media, terutama kepada para pelajar dan anak muda.

Oleh karena itu, artikel ini hendak mendiskripsikan praktik-praktik tradisi Aswaja yang berjalan di MA Matholi'ul Huda Kedung Jepara sebagai salah satu sarana untuk mencegah radikalisme. Ada dua masalah yang akan dibahas dalam artikel ini, yaitu apa saja tradisi Aswaja yang berjalan di MA Matholi'ul Huda Kedung Jepara dan bagaimana tradisi tersebut dibiasakan di lingkungan MA Matholi'ul Huda Jepara. Untuk

13 Eka Prasetiawati, “Menanamkan Islam Moderat Untuk Menanggulangi Radikalisme Di Indonesia," Fikri : Jurnal Kajian Agama, Sosial dan Budaya 2, no. 2 (December 27, 2017): 523-570.

14 Muhammad Mahbubi, Pendidikan Karakter: Implementasi Aswaja Sebagai Nilai Pendidikan Karakter (Yogyakarta: Pustaka Ilmu, 2012), 36. 
itu, kajian ini dilakukan dengan menggunakan pendekatan kualitatif dengan metode studi kasus. Data dalam penelitian ini dikumpulkan dengan teknik observasi peran serta, wawancara, dan dokumentasi. Data kemudian dianalisis secara deskriptif kualitatif melalui tiga tahapan, yaitu penyajian, reduksi, dan verifikasi. Hasil kajian ini diharapkan dapat memberikan gambaran tentang pembiasaan tradisi Aswaja dalam konteks lembaga pendidikan Islam sebagai salah satu cara untuk mencegah radikalisme.

\section{B. Pembiasaan Tradisi Khas Aswaja di Nusantara}

Pembiasaan merupakan salah satu metode pendidikan yang menyasar pada karakter berupa proses penanaman kebiasaan. Kebiasaan itu sendiri adalah cara-cara bertindak yang terus-menerus dan dilakukan secara otomatis. ${ }^{15}$ Dengan demikian, bisa diartikan bahwa pembiasaan adalah cara bertindak yang diperoleh melalui belajar secara berulang-ulang, yang pada akhirnya menjadi konsisten dan bersifat otomatis. Pembiasaan dipercaya sebagai salah satu metode yang paling efektif dalam pembelajaran terutama untuk peserta didik tingkat dasar dan menengah, karena pada usia tersebut seseorang cenderung memiliki rekaman ingatan yang masih kuat dan kondisi kepribadian yang belum matang, sehingga nilai-nilai baru yang ia dapatkan dari pembiasaan tersebut akan mudah tertanam dalam diri mereka. ${ }^{16}$ Karena itu, peserta didik perlu dibiasakan dengan perilaku, keterampilan, dan pola pikir yang baik sehingga mereka mampu berbuat baik tanpa perasaan terpaksa atau menemukan banyak kesulitan. Betapa pentingnya pembiasaan tersebut, Aristoteles hingga pernah mengatakan bahwa manusia adalah apa yang mereka kerjakan secara berulang-ulang, keunggulan bukanlah suatu perbuatan, melainkan sebuah kebiasaan. ${ }^{17}$

Pembiasaan merupakan salah satu metode yang cukup efektif untuk menanamkan nilai-nilai dan moralitas ke dalam diri peserta didik. Nilai-nilai yang tertanam dalam diri tersebut ini akan termanifestasi dalam kehidupan selanjutnya. Pembiasaan terhadap praktik ritual atau ibadah tertentu misalnya, akan melahirkan kebiasaan dalam melakukan ibadah. Dari kebiasaan ibadah itulah, nilai-nilai moral tersebut akan tertanam dalam diri seseorang yang selanjutnya akan menginspirasi

\footnotetext{
${ }^{15}$ Hery Noer Aly, Ilmu Pendidikan Islam (Jakarta: Logos Wacana Ilmu, 2003), 184.

${ }^{16}$ Armai Arief, Pengantar Ilmu Dan Metodologi Pendidikan Islam (Jakarta: Ciputat Press, 2002), 110.

17 Evinna Cinda Hendriana and Arnold Jacobus, "Implementasi Pendidikan Karakter di Sekolah Melalui Keteladanan dan Pembiasaan," JPDI (Jurnal Pendidikan Dasar Indonesia) 1, no. 2 (October 31, 2017): 25-29.
} 
setiap perilaku, perbuatan, perkataan, hingga pola pikir. ${ }^{18}$ Pembiasaan barangkali bisa dimulai dengan paksaan, tetapi sedikit demi sedikit seseorang akan terbiasa. Selanjutnya, jika suatu aktifitas sudah dilakukan dengan rutin, maka ia akan menjadi sebuah kebiasaan, lalu akan menjadi habit atau kebiasaan yang sudah melekat dengan sendirinya dan sulit dihindari. Seseorang yang sudah memiliki suatu kebiasaan tertentu, maka ia akan mampu melakukannya dengan mudah dan senang hati. Bahkan, segala sesuatu yang sudah menjadi kebiasaan di usia muda akan sulit dihilangkan atau dirubah dan akan terus berlangsung hingga tua. ${ }^{19}$

Ada beberapa hal yang perlu diperhatikan dalam menerapkan pembiasaan, antara lain: 1) Pembiasaan hendaknya dimulai sedini mungkin, sebelum peserta didik memiliki kebiasaan yang berlawanan dengan perbuatan yang hendak dibiasakan. 2) Pembiasaan hendaknya dilakukan terus-menerus atau berulang-ulang dan dijalankan secara teratur sehingga akhirnya menjadi suatu kebiasaan yang otomatis. 3) Pembiasaan hendaknya konsekuen, tegas dan tetap teguh terhadap prinsip awal yang telah ditetapkan. Sebisa mungkin, jangan memberi kesempatan kepada peserta didik melanggar pembiasaan yang telah ditetapkan itu. 4) Pembiasaan yang awalnya mekanistis itu lama-kelamaan harus makin menjadi pembiasaan yang dilakukan menurut kata hati sendiri. ${ }^{20}$

Dalam pandangan psikologi behaviorisme, kebiasaan terbentuk karena pengkodisian atau pemberian stimulus. Pemberian stimulus harus dilakukan secara terus-menerus untuk mendapatkan respon yang diinginkan. Ivan Pavlov, salah satu tokoh behaviorisme pernah melakukan eksperimen terhadap seekor anjing untuk membuktikan teorinya yang sangat populer, yaitu classical conditioning. Anjing tersebut dikondisikan dengan diberikan stimulus berupa bunyi lonceng, tetapi anjing tidak memberikan respon apapun. Namun setelah lonceng dibunyikan disertai dengan pemberian daging, anjing tersebut lantas mengeluarkan air liur. Kondisi tersebut kemudian dilakukan berulang-ulang hingga pada gilirannya anjing mengeluarkan air liur ketika lonceng dibunyikan, meski tanpa diberi daging. Dari percobaan itu, Pavlov kemudian menyimpulkan bahwa sebuah tingkah laku yang awalnya sangat sulit dilakukan pada akhirnya dapat menjadi sebuah kebiasaan karena dilakukan berulang-

18 Mustiqowati Ummul Fithriyah and M. Saiful Umam, “Internalisasi Nilai-Nilai Aswaja Dalam Pendidikan Islam Sebagai Upaya Deradikalisasi Menuju Good Citizen," Prosiding Seminar Nasional Islam Moderat 1 (September 24, 2018): 110-124.

19 Qodri A. Azizy, Pendidikan (Agama) Dalam Membangun Etika Sosial (Semarang: Aneka Ilmu, 2013), 147.

20 Syaepul Manan, "Pembinaan Akhlak Mulia Melalui Keteladanan dan Pembiasaan," Ta'lim 15, no. 1 (2017): 49-65. 
ulang. Dengan demikian, untuk menanamkan karakter kepada anak, pembelajaran di kelas saja tidak cukup, tetapi harus disertai dengan pembiasaan sehingga nilai dan moral yang diajarkan kepada peserta didik menjadi sebuah kebiasaan. ${ }^{21}$

Ahl al-sunnah Wa al-Jama'ah atau sering diakronimkan menjadi Aswaja berarti orang yang mengikuti sunnah Rasul saw beserta rombongannya atau jama'ahnya. Istilah Ahl al-Sunnah wa al-Jamaah sendiri sebenarnya belum dikenal di zaman Rasulullah saw maupun di masa pemerintahan al-Khulafa' al-Rasyidin, bahkan tidak dikenal di zaman pemerintahan Bani Umayah. Term Ahl al-Sunnah wa al-Jamaah sebetulnya merupakan diksi baru yang belum pernah digunakan sebelumnya baik di masa Nabi, periode Sahabat, atau tabi'in. ${ }^{22}$ Bahkan pada masa Al-Asy'ari (w. $324 \mathrm{H}$ ), tokoh yang disebut-sebut sebagai pelopor madzhab Ahl al-Sunnah wa al-Jama'ah, istilah ini juga belum digunakan. Sebagai sebuah istilah, Ahl al-Sunnah wa al-Jama'ah baru diperkenalkan hampir empat ratus tahun setelah wafatnya Nabi Saw, oleh para murid dan pengikut al-Asy'ari seperti Al-Baqillani (w. $403 \mathrm{H}$ ), Al-Baghdadi (w. $429 \mathrm{H}$ ), Al-Juwaini (w. $478 \mathrm{H})$, Al-Ghazali (w.505 H), Al-Syahrastani (w. $548 \mathrm{H})$, dan al-Razi (w. $606 \mathrm{H}) .^{23}$

Pemakaian istilah Ahl al-Sunnah wa al-Jama'ah sebagai sebutan bagi kelompok keagamaan justru muncul belakangan, sebagaimana disebutkan oleh Murtadla AzZabidi dalam kitabnya, Ithaf Sadat al-Muttaqin bahwa penyebutan Ahl al-Sunnah wa al-Jama'ah merujuk pada kelompok Asya'irah (pengikut al-Asy'ari) dan Maturidiyah (pengikut al-Maturidi). Dengan kata lain, Aswaja dulu di awal kemunculannya hanya dinisbatkan kepada para pengikut al-Asy'ari dan al-Maturidi dalam hal akidah. Dari sinilah, kemudian Aswaja berkembang tidak hanya dalam bidang kalam atau teologi, tetapi juga dalam bidang fiqih dan tasawuf. Pada akhirnya, Aswaja dirumuskan menjadi golongan yang mengikuti al-Asy'ari dan al-Maturidi dalam bidang akidah, mengikuti madzhab empat (Hanafi, Maliki, Syafi'i dan Hanbali) dan dalam bidang tasawuf atau akhlak mengikuti Al-Ghazali dan al-Junaid al-Baghdadi. Belakangan muncul istilah aqidah sunni, fiqih sunni, atau tasawuf sunni.

Di Nusantara, madzhab Aswaja dibawa dan disebarluaskan oleh para ulama keturunan Timur Tengah yang selanjutnya disebut dengan Walisongo. Hal ini dapat

${ }^{21}$ Lailatus Shoimah and Yerry Soepriyanto, "Pendidikan Karakter Melalui Pembiasaan di Sekolah,” JKTP 1, no. 2 (2018): 169-175.

22 Said Aqil Siradj, Ahlussunnah Wal Jama'ah; Sebuah Kritik Historis (Jakarta: Pustaka Cendikia Muda, 2008), 6.

${ }^{23}$ Harun Nasution, Teologi Islam; Aliran-Aliran, Sejarah Analisa Perbandingan (Jakarta: UI Press, 2008), 65. 
dibuktikan dari tradisi keislaman yang berkembang di Nusantara saat ini yang merupakan ajaran warisan Walisongo. Ajaran ziarah kubur, tawassul, Istighatsah, selametan, adalah ajaran-ajaran Walisongo yang sangat identik dengan ajaran Aswaja. Bukti lain bahwa Walisongo adalah para pembawa ajaran Ahl al-Sunnah juga bisa dilihat dalam primbon peninggalan sunan Bonang. Primbon tersebut selain mengajarkan ilmu fiqih ala madzhab Syafi'i, juga mengajarkan tauhid dan tasawuf yang lengkap dan tersusun rapi menurut ajaran Ahl al-Sunnah wa al-Jama'ah. ${ }^{24}$

Madzhab Ahl al-Sunnah wa al-Jama'ah memiliki prinsip yang pasti terkait dengan tradisi. Dalam menghadapi sebuah tradisi Aswaja berpegang pada kaidah "almuhafadzah "ala al-qadim al-shalih wa al-akhdzu bi al-jadid al-ashlah" yang berarti mempertahankan warisan masa lalu yang baik dan mengkreasi hal baru yang lebih baik. Kaidah inilah yang menuntun madzhab aswaja untuk menjalani kehidupan secara seimbang dan proporsional. Dengan kaidah ini, pengikut aswaja tidak melihat sebuah tradisi dari sisi luarnya, tetapi nilai yang dikandungnya. Jika sebuah tradisi tidak bertentangan dengan ajaran Islam, maka bisa diterima dan dipertahankan. Dengan ini pula, pengikut Aswaja mampu melakukan dialog kreatif dengan tradisi dan budaya untuk mengisi dan melengkapi kekurangan tradisi tersebut agar selaras dengan ajaran Islam. Hal ini penting ditekankan, karena meskipun ditemukan sebuah tradisi yang tidak sejalan, tapi bukan tidak mungkin di dalamnya mengandung nilai-nilai kebaikan. Menghadapi ini, Aswaja memilih bersikap arif dengan tidak menghancurkan semuanya, tetapi mempertahankan unsur-unsur kebaikannya seraya memodifikasi unsur lain yang dianggap menyimpang agar selaras dengan ajaran Islam. ${ }^{25}$

Ambil contoh selametan, kenduri, atau kondangan. Beberapa pihak memandang tradisi-tradisi tersebut sebagai bid'ah atau hal baru yang harus dihilangkan karena merupakan tradisi warisan Hindu-Budha yang tentu saja tidak sesuai dengan ajaran Rasulullah saw. Akan tetapi, pengikut Aswaja memandang tradisi ini secara proporsional. Selametan dalam format aslinya, sebagaimana dipraktikkan oleh masyarakat Jawa Hindu memang mengandung unsur syirik karena di sana terdapat sesajen yang dipersembahkan untuk roh atau makhluk halus. Tetapi bagaimanapun juga, dalam selametan, pasti ada nilai-nilai kebaikan seperti merekatkan tali persaudaraan, syukur kepada Allah, dan mendoakan orang yang sudah meninggal. Semua nilai tersebut baik, dan tidak bertentangan dengan ajaran Islam. Maka, dalam

24 Muhammad Syamsu AS, Ulama Pembawa Islam Di Indonesia Dan Sekitarnya (Jakarta: PT. Lentera Basritama, 1999), 37-38.

${ }^{25}$ Masyhudi Muchtar et al., Aswaja An-Nahdliyah (Surabaya: Khalista, 2007), 35. 
pandangan pengikut Aswaja, selametan tidak perlu dihilangkan, tapi cukup dirubah kontennya agar selaras dengan ajaran Islam. Sesajen kepada makhluk halus diganti dengan sedekah kepada tetangga atau saudara.

Maka bisa dicermati bahwa sebagian besar tradisi Aswaja merupakan tradisi lama warisan masa lalu yang telah dimodifikasi dan diselaraskan dengan ajaran Islam. Di antara tradisi yang berjalan di kalangan Aswaja antara lain:

1. Ziarah Kubur

Kata ziarah berasal dari bahasa Arab yang maksudnya “ kunjungan”. Kata ini pada dasarnya bisa diterapkan untuk segala macam kunjungan, baik berkunjung ke tempat tertentu, orang tua, saudara, ulama, atau berkunjung ke makam. Tetapi, dalam bahasa lokal, ziarah merujuk pada kunjungan kepada tokoh agama, ke tempat-tempat yang dikeramatkan, ke makam Wali, atau ke makam orang tua dan saudara. Dalam pandangan Aswaja, ziarah kubur hukumnya sunnah meskipun Rasul pernah melarang ziarah kubur, tapi pada akhirnya Rasul memperbolehkannya kembali. Ziarah kubur merupakan tradisi yang sudah dilakukan semenjak zaman rasul dan masih dilestarkan sampai sekarang dengan cara dan bentuk yang berbedabeda. ${ }^{26}$

Ziarah kubur selain dimaksudkan untuk mendo'akan orang yang sudah meninggal, juga dimaksudkan untuk tabarruk atau mencari berkah kepada para wali atau ulama yang makamnya diziarahi. Di tempat ziarah tersebut, para peziarah membaca al-Qur'an, tahlil, dzikir-dzikir lain dan doa untuk orang yang diziarahi. Di makam para wali atau ulama, para peziarah juga melakukan tabarruk atau tawassul kepada wali atau ulama tersebut. ${ }^{27}$

2. Yasinan dan Tahlilan

Yasinan adalah tradisi membaca surat Yasin baik secara individual ataupun secara berjama'ah. Tradisi ini biasanya dilakukan setiap malam Jumat baik di rumah warga ataupun di masjid atau mushalla. Bacaan surat Yasin biasanya dihadiahkan kepada orang-orang yang sudah meninggal yang diikuti dengan tahlilan. Hal ini dimaksudkan agar si Mayit mendapatkan ampunan dari Allah sebagaimana penjelasan ibn al-Qayyim al-Jauziyah bahwa barang siapa yang membaca surat Yasin dan menghadiahkan pahalanya kepada orang meninggal, maka orang yang

${ }^{26}$ Kutbuddin Aibak, Fiqih Tradisi Menyibak Keragaman Dalam Keberagaman (Yogyakarta: Teras, 2012), 204.

27 Asep Saifuddin Chalim, Aswaja, Pedoman Untuk Pelajar, Guru, Dan Warga NU (Jakarta: Penerbit Erlangga, 2017), 298. 
meninggal tersebut akan mendapatkan bagian rahmat dan ampunan dari Allah Swt. Ada pula yang membaca surat Yasin di samping orang yang menghadapi detik-detik akhir kehidupan untuk memberikan ketenangan dan mendoakan agar orang yang sedang sekarat tersebut meninggal dengan tenang dan husnul Khatimah. ${ }^{28}$

Sementara kata tahlil bermakna pengucapan kalimat tauhid "La ilaha illa Allah" secara berulang-ulang untuk memohonkan rahmat dan ampunan bagi arwah orang yang meninggal. ${ }^{29}$ Sedangkan secara terminologis Tahlilan yaitu ritual atau kegiatan keagamaan yang diisi dengan membaca tahlil. Tahlilan biasanya dilakukan oleh sebagian umat Islam setelah seseorang meninggal dunia. Dalam upacara tersebut, pembacaan tahlil dilakukan setidaknya 100 kali. Selain mengucapkan tahlil, dibacakan juga ayat-ayat Al-Qur'an, Sholawat Nabi, dan bacaan-bacaan lain. Kegiatan ini kemudian ditutup dengan do'a untuk keselamatan orang yang telah meninggal dan keteguhan hati bagi keluarga yang ditinggalkan. ${ }^{30}$

Adapun penyebutan nama "tahlilan" karena bacaan La Ilaha Illa Allah adalah bacaan yang paling dominan di antara bacaan lain semacam hamdalah, tasbih atau, shalawat. Kegiatan tahlil atau Tahlilan ini bertujuan untuk mendo'akan arwah nenek moyang yang telah mendahului agar diampuni segala dosa dan diterima semua amal baiknya. ${ }^{31}$

3. Selametan kematian

Selain Yasinan dan Tahlilan yang dilaksanakan secara rutin untuk arwah orang yang sudah meninggal, masyarakat muslim nusantara juga memiliki tradisi selametan kematian. Tradisi ini biasanya dilakukan mulai hari pertama meninggalnya anggota keluarga hingga hari ke tujuh, kemudian dilanjutkan pada hari ke 40, 100, dan 1000 hari setelah kematian. Setelah seribu hari, masyarakat muslim nusantara mengadakan upacara haul atau mendak untuk setiap tahunnya. Upacara selametan kematian ini umumnya diisi dengan pembacaan surat Yasin dilanjutkan tahlil dan sedekah yang dihadiahkan untuk si mayit. ${ }^{32}$

4. Manaqiban dan Maulid Nabi

Manaqib berarti sejarah hidup seseorang yang berisikan tentang prilaku, akhlak, dan kelebihan-kelebihan yang patut dijadikan suri tauladan. Maksud dari

\footnotetext{
28 Ibid.

29 Pusat Bahasa, Kamus Bahasa Indonesia (Jakarta: Pusat Bahasa Depdiknas, 2008), 1590.

30 Boenjamin Setiawan, Eduardus Nugroho, and Budi Santoso Tanuwibowo, Ensiklopedi Nasional Indonesia, vol. 16 (Jakarta: PT. Cipta Adi Pustaka, 1991), 17.

31 Muhyiddin Abdusshomad, Tahlil Dalam Perspektif Al-Qur'an Dan As-Sunnah (Jember: PP. Nurul Islam, 2005), xii.

${ }^{32}$ Chalim, Aswaja, Pedoman Untuk Pelajar, Guru, Dan Warga NU.
} 
tradisi manaqiban diantaranya untuk bertawasul, memperoleh berkah, dan lebih mengenal orang sholih tersebut agar dapat lebih mencintainya dan meneladani akhlak dan perilakunya. Selain itu, para ulama menjelaskan, bahwa mengenang orang-orang shalih dapat menurunkan rahmat dan berkah. Tradisi manaqiban merupakan salah satu tradisi masyarakat muslim yang sudah berlangsung lama. Di Jawa misalnya, umat Islam mengadakan manaqiban Syaikh Abdul Qadir al-Jilani, pendiri tarekat Qadiriyah, sementara di daerah Kalimantan, banyak yang mengadakan manaqib Syaikh Muhammad ibn Abdul Karim al-Samman, pendiri tarekat Sammaniyah.

Adapun Maulid Nabi, selain menjadi tradisi masyarakat Muslim Indonesia juga telah menjadi tradisi muslim Sunni di seluruh belahan dunia. Seperti halnya Manaqiban, dalam Maulid Nabi biasanya dibacakan kisah dan sejarah hidup Rasulullah mulai kelahiran hingga wafatnya. Ini penting untuk mengajarkan keteladanan hidup Rasullullah dan meningkatkan kecintaan umat kepada sang Rasul. $^{33}$

\section{Tradisi Ruwahan dan Nyadran}

Ruwahan adalah salah satu tradisi muslim Indonesia yang dijalankan dalam rangka mengisi bulan Sya'ban. Dalam ajaran Islam, bulan Sya'ban dianggap sebagai salah satu bulan istimewa karena berdasarkan hadits Nabi pada bulan Sya'ban perbuatan manusia dilaporkan kepada Allah swt. Untuk menghadapi bulan tersebut, maka umat Islam di tanah air mengisinya dengan puasa dan memperbanyak sedekah. Pada malam nishfu Sya'ban atau malam 15 bulan Sya'ban, umat Islam juga melaksanakan shalat sunah berjama'ah dan doa bersama. Tradisi ini biasa disebut dengan istilah Ruwahan. Mengingat bulan Sya'ban juga disebut sebagai bulan arwah, maka pada bulan ini umat islam di Indonesia juga melakukan ziarah kubur dan memperbanyak do'a untuk arwah leluhur. ${ }^{34}$

6. Istighatsah

Istighosah maksudnya adalah meminta pertolongan kepada Allah swt. Kalangan umat Islam di Nusantara berhubungan sangat erat dengan tradisi istighosah ini. Istighosah sangat dianjurkan oleh agama, terutama ketika memiliki hajat dalam skala besar dan memerlukan energi yang besar pula untuk mencapainya. Dalil Istighatsah bisa ditemukan di banyak hadits sehingga tradisi ini

\footnotetext{
${ }^{33}$ Chalim, Aswaja, Pedoman Untuk Pelajar, Guru, Dan Warga NU.

34 Ibid.
} 
sudah dijalankan oleh kaum muslimin mulai para ulama generasi salaf hingga saat ini. ${ }^{35}$

\section{Tradisi Ngapati dan Mitoni atau Tingkepan}

Tradisi ngapati adalah upacara selametan saat kehamilan menginjak usia 4 bulan. Sementara mitoni atau tingkepan adalah selametan ketika umur kehamilan menginjak usia 7 bulan. Upacara ini dimaksudkan untuk mendo'akan janin yang dikandung beserta ibu yang mengandung diberikan keselamatan dan kesehatan, dan kelak janin yang dilahirkan menjadi anak yang shaleh. Upacara ini biasanya diisi dengan membaca al-Qur'an, khususnya surah Yusuf dan Maryam, doa bersama, dan bersedekah. Terkait dengan adanya tradisi ini, dalam ajaran para ulama klasik dikenal istilah walimat al-haml, yaitu upacara menyambut kehamilan seseorang. Sama seperti tradisi Ngapati atau Mitoni, dalam upacara walimat al-haml ini juga dianjurkan untuk mendoakan ibu dan janin serta mengeluarkan sedekah. ${ }^{36}$

8. Tradisi bulan Shafar

Untuk mengisi bulan Shafar, para ulama Nusantara menganjurkan agar kaum muslimin memperbanyak bersedekah. Oleh karena itu, kaum muslimin di Indonesia memiliki tradisi bersedekah dengan bubur shafar (tajin shafar). Bubur tersebut dibuat dari beras ketan kemudian dibagikan kepada saudara dan tetangga dengan maksud untuk menolak balak dan musibah. Selain sedekah, sebagian umat Islam juga melakukan doa bersama di hari rabu terakhir di bulan Shafar dan membuat minuman yang dibacakan doa agar terhindar dari malapetaka. Hal ini karena, ada sebuah hadits yang mengatakan bahwa hari rabu terakhir bulan shafar adalah hari turunnya berbagai malapetaka ke dunia.

9. Tradisi bulan Suro

Dalam ajaran Islam, bulan Muharram atau orang Jawa menyebutnya dengan bulan Sura merupakan salah satu bulan yang dimulyakan (ayshur al-hurum). Karena itu, umat islam dianjurkan untuk berpuasa pada sepuluh hari pertama di bulan, terlebih pada tanggal 9 dan 10 Muharram (hari tasu'a' dan 'Asyura). Pada bulan ini ada beberapa amalan yang disunnahkan antara lain berpuasa, bersedekah, menyantuni anak yatim, dan memperbanyak ibadah dan dzikir. Dalam rangka menerapkan anjuran itu, masyarakat muslim Nusantara di berbagai daerah

${ }^{35}$ Zuhairi Misrawi, Hadratussyaikh Hasyim Asy'ari Moderasi, Keumatan, Dan Kebangsaan (Jakarta: Kompas Media Nusantara, 2010), 107-108.

36 Iswah Adriana, "Neloni, Mitoni, atau Tingkepan: (Perpaduan antara Tradisi Jawa dan Ritualitas Masyarakat Muslim)," Karsa 19, no. 2 (2011): 238-247. 
menggelar perayaan atau upacara yang diisi dengan berbagai kegiatan seperti dzikir dan doa bersama, sedekah, pawai hingga penampilan berbagai macam kesenian tradisional. $^{37}$

Selain tradisi-tradisi di atas, banyak amaliah khas Aswaja lain yang sudah berlaku di kalangan muslim Sunni di Nusantara seperti khatmil Qur'an berjama'ah, talqin mayit, puji-pujian sebelum shalat fardlu berjama'ah, shalawatan, salaman setelah shalat fardlu, dan lain sebagainya.

\section{Pembiasaan Tradisi Aswaja di MA Matholi'ul Huda Jepara}

Islam sejatinya tidak identik dengan ekstremisme dan kekerasan. Sesuai catatan sejarah, islam yang datang ke Nusantara lebih mendahulukan cara-cara damai yang membuat Islam bisa hadir dan menjadi bagian tak terpisahkan dari kehidupan masyarakat Indonesia selama ratusan tahun. Karena itulah madzhab Aswaja menolak paham Islam yang cenderung radika. Aswaja tidak setuju dengan respons dan penyelesaian persoalan melalui jalan kekerasan, pemaksaan, apalagi dengan anarkhisme. Aswaja juga menolak terhadap eksistensi kelompok-kelompok yang menutup diri dari golongan mayoritas kaum Muslimin.

Penanaman nilai-nilai Aswaja di tingkat lembaga pendidikan seperti sekolah atau madrasah bisa dilakukan melalui jalur pendidikan yang diharapkan dapat memberikan pemahaman atas ajaran Islam yang moderat. Pendidikan Aswaja mempunyai potensi dan peran yang sangat besar dalam rangka mencegah dan mengcounter persebaran arus Islam radikal. Alasannya, Aswaja ialah sistem keberagamaan yang menjunjung tinggi moderatisme. Ajaran Aswaja bisa dijadikan sebagai sarana untuk membangun pemahamaan dan praktik Islam yang toleran, inklusif serta moderat. Tidak hanya itu, Aswaja yang tertanam dalam diri seseorang sebagai pemahaman, prinsip, serta perilaku ialah modal berarti untuk bersikap kritis dalam mengalami dinamika sosial keagamaan yang terus menjadi komplek.

“..Implementasi pendidikan Aswaja di lembaga ini diwujudkan melalui pembelajaran di dalam kelas melalui mata pelajaran Aswaja sebagai muatan lokal. Pendidikan Aswaja diwujudkan melalui program ekstrakurikuler yang dapat menunjang pengetahuan Aswaja peserta didik seperti pengajian, Tilawatil Qur'an, kerohanian, dan lain-lain.."38

\footnotetext{
37 Damar Safera and Muhammad Chairul Huda, "Tradisi Suroan Sebagai Tapak Tilas Walisongo (Studi Di Desa Jatirejo Kecamatan Suruh Kabupaten Semarang)," Al-Mada: Jurnal Agama, Sosial, dan Budaya 3, no. 1 (March 25, 2020): 66-79.

${ }^{38}$ Sarwadi, Kepala MA Matholi'ul Huda Kedung, Wawancara, Jepara, 2 Februari 2020.
} 
Selain dua program tersebut, penanaman nilai-nilai Aswaja di MA Matholi'ul Huda Kedung Jepara juga dilakukan dengan pembiasaan tradisi-tradisi Aswaja di lingkungan sekolah atau madrasah. Selain berguna untuk pelestarian tradisi warisan leluhur tersebut, pemeliharaan tradisi keagamaan Nusantara juga bisa menjadi sarana yang potensial untuk menanamkan nilai-nilai moderatisme untuk mencegah paham radikal.

Tradisi-tradisi keagamaan Aswaja dengan semua nilai-nilainya yang kini terpelihara di kalangan umat Islam Nusantara adalah wujud penghargaan terhadap leluhur, para ulama, dan para pejuang yang berjuang untuk islam dan bangsa ini. Tradisi-tradisi tersebut mengajarkan beragam nilai luhur seperti silaturrahim, persatuan, solidaritas sosial, dan lain-lain. Kecuali itu, dengan memelihara sejumlah tradisi, ritual, upacara dan segenap praktik-praktik keagamaan, kesenian, dan kebudayaan akan dapat menghubungkan satu generasi ke generasi selanjutnya, dari satu komunitas ke komunitas lainnya sehingga solidaritas berbangsa, persatuan dan kebersamaan di antara komponen bangsa ini tetap terjaga dengan baik. ${ }^{39}$

Berdasarkan hasil wawancara penulis dengan Bapak Ngizudin Kurniawan, Waka Kurikulum MA Matholi'ul Huda Kedung Jepara, ada beberapa kegiatan pembiasaan tradisi Aswaja. Berikut pemaparannya:

“..Di Lembaga ini terdapat berbagai kegiatan-kegiatan pembiasaan keagamaan keaswajaan diantaranya adalah sholat dhuhur dan dzikir berjama'ah, ziarah bersama ke makam pendiri dan para wali menjelang ujian, istightsah, dan lain-lain." 40

Di antara tradisi-tradisi keagamaan Aswaja yang dijalankan di MA Matholi'ul Huda Kedung Jepara antara lain:

1. Khotmil Qur'an dan Tahlilan

Kegiatan Khotmil Qur'an bersama adalah kegiatan membaca Al-Qur'an yang dilakukan secara bersama-sama mulai dari surat Al-Fatihah sampai pada surat Annas secara serentak dalam satu waktu. Kegiatan khotmil Qur'an di MA Matholi'ul Huda Kedung Jepara ini dilaksanakan secara bergiliran di antara peserta didik MA Matholi'ul Huda Jepara.

"Khatmil Qur'an dimulai hari Sabtu, Minggu, dan Senin untuk peserta didik putra secara berurutan dari kelas X, XII dan XII. Kemudian hari Selasa, Rabu dan kamis giliran peserta didik putri secara berurutan dari kelas X, XI dan XII. Setelah

\footnotetext{
${ }^{39}$ Ahmad Baso, “Kembali Ke Pesantren, Kembali Ke Karakter Ideologi Bangsa," KARSA: Journal of Social and Islamic Culture 20, no. 1 (July 10, 2012): 1-20.

40 Ngizudin Kurniawan, Waka Kurikulum MA Matholi'ul Huda Kedung, Wawancara, Jepara, 5 Februari 2020.
} 
pembacaan al-Qur'an selesai kemudian dilanjutkan dengan tahlil dan ditutup dengan doa khotmil Qur'an.."41

Makna dari kegiatan khotmil Qur'an bersama ini adalah mengaharapkan syafaat dan barakah dari adanya khataman Al-Qur'an untuk diri sendiri, keluarga yang masih hidup maupun yang telah meninggal. Kegiatan khataman Qur'an ini juga bertujuan untuk meningkatkan motivasi peserta didik dalam mempelajari, mengamalkan serta mensyi'arkan Al-Qur'an di dalam kehidupannya. Ketika peserta didik terbiasa dengan membaca Al-Qur'an maka peserta didik akan memotivasi diri untuk mempelajari dan mengamalkan ajaran Islam sehingga kehidupan mereka lebih tertata dan dapat dijadikan teladan di masa depan.

\section{Istighatsah}

Kegiatan Istighotsah yang dilakukan MA Matholi'ul Huda Kedung Jepara dilakukan menjelang ujian semester atau ujian nasional yang diikuti oleh semua peserta didik beserta semua guru. Tujuan dari kegiatan istighosah ini adalah menguatkan mental dan spiritual peserta didik yang akan menjalankan Ujian Nasional, mendoakan agar peserta didik perpaham lurus sesuai dengan ajaran Nabi Muhammad SAW, serta menjadi peserta didik yang berakhlakul karimah. Hal ini disampaikan oleh Bapak Ah. Mudlofar, Waka Kesiswaan berikut ini:

“..Setiap minggu guru-guru mengadakan Istighosah sekaligus forum koordinasi guru untuk mendoakan anak didik agar berpaham lurus dan tidak tersesat sesuai dengan ajaran Nabi Muhammad SAW. Istighosah juga diadakan bersama pesrta didik dan Wali menjelang Ujian Nasional untuk mendoakan kesuksesan dan kelancaran UN. Hakekat kegiatan Istighatsah memang untuk mendekatkan diri kepada Allah SWT, tetapi juga banyak manfaat yang lain seperti mempunyai rasa bersyukur atas karunianya dan juga mempererat Ukhuwah dan menanamkan nilai Ahlussunah wal Jama'ah agar melekat dalam pribadi masing-masing peserta didik.."42

Penanaman nilai-nilai ukhuwah baik ukhuwah Islamiyah maupun wathaniyah ini penting karena bangsa Indonesia terdiri dari berbagai suku, ras, dan agama wajib tetap bersatu dalam wadah Indonesia dalam semangat Bhinneka Tunggal Ika. ${ }^{43}$

Ukhuwah yang tertanam dalam diri peserta didik ini akan menangkis segala hal yang menjerumus pada kekerasan yang dekat radikalisme. Ukhuwah islamiyah menjadi modal untuk melakukan pergaulan sosial sesama umat yang menjadikan hubungan antar sesama muslim harmonis dan mampu menjadi sebuah kekuatan besar membumikan nila-nilai Islam. Ukhuwah wathaniyah menjadi sebuah

41 Ngizudin Kurniawan, Waka Kurikulum MA Matholi'ul Huda Kedung, Wawancara, Jepara, 15 Februari 2020.

${ }^{42}$ Ah. Mudlofar, Waka Kesiswaan MA Matholi'ul Huda Kedung, Wawancara, Jepara, 17 Februari 2020

43 Ahmad Ihwanul Muttaqin and Syaiful Anwar, "Dinamika Islam Moderat," TARBIYATUNA 12, no. 1 (February 15, 2019): 20-38. 
komitmen persaudaraan yang damai dan saling menghargai kepada seluruh masyarakat yang terdiri dari bermacam-macam agama, suku, bahasa dan budaya. Ukhuwah insaniyah menjadi kunci dari semua persaudaraan terlepas dari status agama dan suku bangsa. Karena nilai utama dari persaudaraan ini adalah kemanusiaan.

3. Ziarah Kubur

MA Matholi'ul Huda Kedung Jepara memiliki tradisi ziarah ke makam para pendiri madrasah, para ulama, dan para wali menjelang ujian Nasional. Kegiatan ini diikuti semua peserta didik kelas XII beserta semua guru. Kegiatan ziarah kubur ini dilakukan untuk memantapkan mental para peserta didik agar semakin optimis dan percaya diri dalam melaksanakan ujian.

“..Manfaat dari kegiatan ziarah ini adalah untuk mencari berkah kepada para ulama dan wali Allah, meningkatkan spiritualitas peserta didik, dan memberikan ketenangan hati ketika berada dalam makam para wali saat berdzikir. Di luar itu, kegiatan ziarah kubur juga dilakukan di awal tahun pelajaran baru.." 44

Dengan kegiatan ziarah kubur ini diharapkan dapat menanamkan nilai-nilai Aswaja pada peserta didik. Peserta didik yang membiasakan diri melakukan ziarah tentu tidak akan memiliki anggapan bahwa makam para Wali tersebut adalah sarang khurafat dan kemusyrikan. Hal ini berkebalikan dengan pemahaman sebagian muslim yang menganggap makam para wali adalah sarang khurafat yang harus dihancurkan. Dengan demikian, kegiatan ziarah kubur ini memberikan pemahaman kepada peserta didik tentang perlunya menghargai para ulama terdahulu dan menjaga tempat makam bersejarah.

\section{Tawassul}

Tawassul merupakan salah satu amaliah khas Aswaja yang sudah melekat erat di kalangan muslim tanah air. Hal ini disampaikan oleh Bapak Sarwadi, berikut ini:

“..Di MA Matholi'ul Huda Jepara, kegiatan tawassul dilakukan sepaket dengan ziarah kubur, ziarah wali, atau manaqiban. Kegiatan tawassul kepada para ulama atau wali di MA Mathol'ul Huda Jepara biasanya dilakukan menjelang pelaksanaan Ujian Nasional..." 45

Lebih lanjut, Bapak Ah. Mudlofar, Waka Bidang Kesiswaan menyampaikan:

\footnotetext{
${ }^{44}$ Mochammad Solikin, Guru Aqidah Akhlaq dan SKI di MA Matholi'ul Huda Kedung, Wawancara, Jepara, 2 Februari 2020.

45 Sarwadi, Kepala MA Matholi’ul Huda Kedung, Wawancara, Jepara, 2 Februari 2020.
} 
“..Dengan bertawassul, diharapkan peserta didik akan mendapatkan berkah dari para ulama dan wali yang diyakini sebagai orang-orang suci yang dekat dengan Allah sehingga peserta didik mampu melewati ujian nasional dengan lancar dan sukses.."46

Dalam tradisi tawassul terdapat sebuah pelajaran penting bahwa manusia tidak boleh merasa paling beriman, paling agamis, atau paling dekat dengan Tuhan. Tawassul mengajarkan nilai kerendahan hati dan tawadlu' bahwa manusia di hadapan Allah swt adalah kecil belaka. Seorang hamba yang merasa kecil di hadapan Tuhan tentu merasa tidak pantas memohon langsung kepada Allah Swt, sehingga membutuhkan bantuan dari orang yang pantas dan lebih dekat dengan Allah, yaitu para wali dan ulama. Karakter tawadlu' inilah yang hendak ditanamkan kepada peserta didik melalui tawassul sehingga tidak akan merasa paling benar sendiri dan menyalahkan orang lain.

Dari uraian di atas, bisa dipahami bahwa tradisi-tradisi keagamaan ala Aswaja memiliki nilai-nilai luhur, baik dari sisi akidah, moral, maupun sosial yang penting untuk ditanamkan di kalangan pelajar dan remaja. Sebagaimana karakter madzhab Aswaja yang moderat, tradisi-tradisi tersebut juga mengajarkan nilai-nilai luhur yang berpotensi menjadi kontra narasi bagi penyebaran radikalisme.

\section{Kesimpulan}

Nilai-nilai Aswaja menjadi salah satu vaksin yang ampuh dalam upaya mencegah sekaligus melawan penyusupan radikalisme. Untuk mengajarkan nilai-nilai tersebut, banyak jalan yang bisa ditempuh. Salah satunya adalah melalui pembiasaan terhadap praktik tradisi Aswaja yang telah diwariskan oleh para ulama terdahulu. Pembiasaan tradisi Aswaja, terutama di lembaga pendidikan Islam, sangatlah penting karena dalam setiap tradisi tersebut terdapat beragam nilai-nilai luhur yang akan menjadi pijakan dan inspirasi peserta didik dalam mengarungi kehidupan ke depan. Pembiasaan tradisi tersebut juga merupakan bentuk pembelajaran agar mereka memiliki sikap kepedulian terhadap tradisi dan penghargaan terhadap para ulama yang telah memulai tradisi tersebut. Sikap peduli dan menghargai inilah yang pada gilirannya akan menjadi penangkal sekaligus penawar bagi racun radikalisme.

\section{E. Referensi}

Abdillah, Junaidi. "Radikalisme Agama: Dekonstruksi Tafsir Ayat-Ayat 'Kekerasan'

\footnotetext{
${ }^{46}$ Ah. Mudlofar, Waka Kesiswaan MA Matholi'ul Huda Kedung, Wawancara, Jepara, 5 Februari 2020.
} 
Dalam Al-Qur'an." KALAM 8, no. 2 (February 22, 2017): 281-300.

Abdusshomad, Muhyiddin. Tahlil Dalam Perspektif Al-Qur'an Dan As-Sunnah. Jember: PP. Nurul Islam, 2005.

Adriana, Iswah. "Neloni, Mitoni, atau Tingkepan: (Perpaduan antara Tradisi Jawa dan Ritualitas Masyarakat Muslim)." Karsa 19, no. 2 (2011): 238-247.

Aibak, Kutbuddin. Fiqih Tradisi Menyibak Keragaman Dalam Keberagaman. Yogyakarta: Teras, 2012.

Aly, Hery Noer. Ilmu Pendidikan Islam. Jakarta: Logos Wacana IImu, 2003.

Arief, Armai. Pengantar Ilmu Dan Metodologi Pendidikan Islam. Jakarta: Ciputat Press, 2002.

Azizy, Qodri A. Pendidikan (Agama) Dalam Membangun Etika Sosial. Semarang: Aneka Ilmu, 2013.

Baso, Ahmad. "Kembali Ke Pesantren, Kembali Ke Karakter Ideologi Bangsa." KARSA: Journal of Social and Islamic Culture 20, no. 1 (July 10, 2012): 1-20.

Chalim, Asep Saifuddin. Aswaja, Pedoman Untuk Pelajar, Guru, Dan Warga NU. Jakarta: Penerbit Erlangga, 2017.

El-Said, Hamed. New Approaches to Countering Terrorism Designing and Evaluating Counter Radicalization and De-Radicalization Programs. London: Palgrave Macmillan, 2015.

Fithriyah, Mustiqowati Ummul, and M. Saiful Umam. "Internalisasi Nilai-Nilai Aswaja Dalam Pendidikan Islam Sebagai Upaya Deradikalisasi Menuju Good Citizen." Prosiding Seminar Nasional Islam Moderat 1 (September 24, 2018): 110-124.

Hasani, Ismail, and Bonar Tigor Naipospos. Dari Radikalisme Menuju Terorisme. Jakarta: Pustaka Masyarakat Setara, 2012.

Hendriana, Evinna Cinda, and Arnold Jacobus. "Implementasi Pendidikan Karakter di Sekolah Melalui Keteladanan dan Pembiasaan." JPDI (Jurnal Pendidikan Dasar Indonesia) 1, no. 2 (October 31, 2017): 25-29.

Indonesia, Media. "Sekolah Larang Hormat Bendera." Mediaindonesia.Com, September 1, 2016. http://mediaindonesia.com/news/read/64540/sekolah-larang-hormatbendera/2016-09-01.

Kompas. "Larang Murid Hormat Bendera Dan Sungkem Orangtua, Guru SD Diberhentikan." Kompas.Com, January 26, 2016. http://regional.kompas.com/read/2016/01/26/11533721/Larang.Murid. Hormat. Bendera.dan.Sungkem.Orangtua.Guru.SD.Diberhentikan.

Mahbubi, Muhammad. Pendidikan Karakter: Implementasi Aswaja Sebagai Nilai Pendidikan Karakter. Yogyakarta: Pustaka Ilmu, 2012.

Manan, Syaepul. "Pembinaan Akhlak Mulia Melalui Keteladanan dan Pembiasaan." Ta'lim 15, no. 1 (2017): 49-65. 
Mansyur, Wasid. Menegaskan Islam Indonesia, Belajar Dari Tradisi Pesantren Dan NU. Surabaya: Pustaka Idea, 2014.

Misrawi, Zuhairi. Hadratussyaikh Hasyim Asy'ari Moderasi, Keumatan, Dan Kebangsaan. Jakarta: Kompas Media Nusantara, 2010.

Muchtar, Masyhudi, A. Rubaidi, A. Zainul Hamdi, Maftuhin, and Andre. Aswaja AnNahdliyah. Surabaya: Khalista, 2007.

Muttaqin, Ahmad Ihwanul, and Syaiful Anwar. "Dinamika Islam Moderat." TARBIYATUNA 12, no. 1 (February 15, 2019): 20-38.

Naim, Ngainun. "Deradicalization Through Islamic Education at State Institute for Islamic Studies (IAIN) Tulungagung." Madania 22, no. 2 (2018): 211-224.

---. "Pengembangan Pendidikan Aswaja sebagai Strategi Deradikalisasi." Walisongo: Jurnal Penelitian Sosial Keagamaan 23, no. 1 (June 15, 2015): 69-88.

Nasution, Harun. Teologi Islam; Aliran-Aliran, Sejarah Analisa Perbandingan. Jakarta: UI Press, 2008.

Prasetiawati, Eka. "Menanamkan Islam Moderat Untuk Menanggulangi Radikalisme Di Indonesia." Fikri : Jurnal Kajian Agama, Sosial dan Budaya 2, no. 2 (December 27, 2017): 523-570.

Pusat Bahasa. Kamus Bahasa Indonesia. Jakarta: Pusat Bahasa Depdiknas, 2008.

Rokhmad, Abu. "Radikalisme Islam dan Upaya Deradikalisasi Paham Radikal." Walisongo: Jurnal Penelitian Sosial Keagamaan 20, no. 1 (May 30, 2012): 79-114.

Safera, Damar, and Muhammad Chairul Huda. "Tradisi Suroan Sebagai Tapak Tilas Walisongo (Studi Di Desa Jatirejo Kecamatan Suruh Kabupaten Semarang)." AlMada: Jurnal Agama, Sosial, dan Budaya 3, no. 1 (March 25, 2020): 66-79.

Setiawan, Boenjamin, Eduardus Nugroho, and Budi Santoso Tanuwibowo. Ensiklopedi Nasional Indonesia. Vol. 16. Jakarta: PT. Cipta Adi Pustaka, 1991.

Shoimah, Lailatus, and Yerry Soepriyanto. "Pendidikan Karakter Melalui Pembiasaan di Sekolah.” JKTP 1, no. 2 (2018): 169-175.

Singh, Bilveer. "Terrorist Attacks in Indonesia: Insights for Practicioners and Policymakers." In Learning From Violent Extremist Attacks: Behavioural Sciences Insights For Practitioners And Policymakers. Toh Tuck Link, Singapore: World Scientific, 2019.

Siradj, Said Aqil. Ahlussunnah Wal Jama'ah; Sebuah Kritik Historis. Jakarta: Pustaka Cendikia Muda, 2008.

Syamsu AS, Muhammad. Ulama Pembawa Islam Di Indonesia Dan Sekitarnya. Jakarta: PT. Lentera Basritama, 1999.

Wahyudin, Didin. "Pendidikan Aswaja sebagai upaya menangkal radikalisme." Dinamika Penelitian: Media Komunikasi Penelitian Sosial Keagamaan 17, no. 2 (2017): 291-314. 


\section{Hasil Wawancara}

Sarwadi, Kepala MA Matholi'ul Huda Kedung, Wawancara, Jepara, 2 Februari 2020.

Ngizudin Kurniawan, Waka Kurikulum MA Matholi'ul Huda Kedung, Wawancara, Jepara, 5 Februari 2020.

Ah. Mudlofar, Waka Kesiswaan MA Matholi'ul Huda Kedung, Wawancara, Jepara, 17 Februari 2020

Mochammad Solikin, Guru Aqidah Akhlaq dan SKI di MA Matholi'ul Huda Kedung, Wawancara, Jepara, 2 Februari 2020. 